\title{
Two Bacillus Species Isolated from Rotting Wood Samples are Good Candidates for the Production of Bioethanol using Agave Biomass
}

Yagya Prasad Paudel and Wensheng Qin*

Department of Biology, Lakehead University, Thunder Bay, Canada

\begin{abstract}
The biorefining of crop and plant organic matter represents a promising route to produce renewable fuels and bioproducts. The high contents of cellulose and hemicellulose make Agave americana an ideal candidate to produce value-added products. In this study, two different cellulase producing bacteria, isolated from rotting wood samples, were incubated and cultivated to examine their ability to decompose agave and produce ethanol. The results showed the transparent zones called halos on the plates containing Agave as the sole carbon source after iodine staining for these two isolates and positive control Cellulomonas xylanilytica; while, no halo was observed for negative control: Escherichia coli BL21. The Bacillus species K1 and A0 displayed hydrolysis ability greater than that of positive control based on halo diameter. Moreover, the quantitative ability to decompose agave was studied for the same two bacterial strains using minimal salt media containing $5 \%$ agave biomass. Dinitrosalicylic acid (DNS) method was used to detect cellulase and reducing sugars. Ethanol was detected by using micro-dichromate method. The results showed that strain $\mathrm{K} 1$ produced $0.435 \mathrm{~g}$ ethanol $/ \mathrm{g}$ Agave biomass and the isolate A0 produced $0.397 \mathrm{~g} / \mathrm{g}$ ethanol on the $4^{\text {th }}$ day of incubation.
\end{abstract}

Keywords: Agave; Lignocellulosic biomass; Bacillus; Cellulase; Bioethanol

\section{Introduction}

With the exhaustion of non-renewable fossil fuels leading to environmental pollution and energy crisis, there is a demand for new renewable sources of energy. Biofuels are the renewable source of energy which is environmentally friendly with low carbon dioxide emission. Agricultural biomass and other cellulose based wastes are the good sources for production of biofuels.

Bioethanol is the biofuel mostly useful for transportation worldwide. It can be produced from different raw materials such as simple sugars, starch, agricultural products, and lignocellulosic biomass. Recent production of bioethanol is dependent on starch and sugars from existing food crops [1]. Although it might be beneficial to use renewable plant materials for bio-fuel, the use of crop residues and other biomass for bio-fuels raises many concerns about major environmental problems such as food shortages and serious destruction of vital soil resources [2]. The availability of raw materials for the production is one of the major problems associated with the bioethanol production. To overcome this problem, lignocellulosic biomass constitutes the world's largest bioethanol renewable source. The production of bioethanol from lignocellulosic biomass is one way for reducing the consumption of petroleum oil and environmental pollution. Also, the lignocellulosic biomass is the most promising feedstock considering its great availability and low cost. However, the large-scale commercial production of fuel bioethanol from lignocellulosic materials has not been implemented. The main reason for this is the production cost of bioethanol from lignocellulose is too high due to enzyme production cost.

Agave can grow in a dry land with limited water supply and the biofuel produced from Agave biomass has very low $\mathrm{CO}_{2}$ emissions (35 $\mathrm{g} / \mathrm{J}$ ); whereas there is higher $\mathrm{CO}_{2}$ emission from corn based biofuel ( 85 $\mathrm{g} / \mathrm{J})$ [3]. Agave consists of natural fibers which can be degraded to a large number of bioproducts and value added products like bioethanol and xylitol [4]. So, this plant has potential application for the bioethanol productions. Its fibers are rich source of cellulose (68\%) and other components are hemicelluloses (15\%), lignin (5\%), wax $(0.26 \%)$, and moisture (8\%) [5]. Cellulose is a polysaccharide formed by D-glucose units linked together by 1,4-glycosidic bonds and is insoluble in water but can be hydrolysed by acid, hemicellulose is composed of mainly the pentoses and hexoses and is not soluble in water but soluble in alkali and easily hydrolysed in diluted acids. Lignin is a complex phenolic polymer and is not soluble in water. The main role of lignin is to provide structural support, prevent oxidation and protect the cell against the microbial invasion.

For the production of bioethanol from lignocellulosic biomass, the cellulose is typically hydrolysed by an enzyme called cellulase. Microorganisms mainly the fungi and bacteria are the good candidates for lignocellulosic biomass degradation. Fungi such as Trichoderma, Aspergillus, Schizophyllum and Penicillium are widely used to produce cellulases [6]. Bacteria belonging to Clostridium, Bacillus, Thermomonospora and Ruminococcus can produce cellulases effectively as well [7]. Bacteria offer several benefits over the fungi for the degradation process of biomass as they have high growth rates as compared with fungi and other microorganisms. Also, bacteria can adapt to different types of environmental conditions in a wide range of $\mathrm{pH}$ and temperature. They can also be genetically engineered to increase the catalytic activity for the enzymes degrading lignocellulosic biomass [8]. This study aims the production of bioethanol by using two bacterial strains which have ability for the hydrolysis and fermentation of Agave biomass.

\section{Material and Methods}

\section{Chemicals and bacterial strains}

All the chemicals used in this research were of analytical grade. Agave americana biomass (untreated) was obtained from the Biotechnology Laboratory for Enzymes and Bioproducts, Lakehead University, Canada. The cellulase production and Agave biomass degrading

*Corresponding author: Wensheng Qin, Department of Biology, Lakehead University, Thunder Bay, Canada, Tel: (807) 343-8467; Fax: (807) 346-7796; E-mail: wqin@lakeheadu.ca

Received July 13, 2015; Accepted August 05, 2015; Published August 12, 2015

Citation: Paudel YP, Qin W (2015) Two Bacillus Species Isolated from Rotting Wood Samples are Good Candidates for the Production of Bioethanol using Agave Biomass. J Microb Biochem Technol 7:4 218-225. doi:10.4172/1948-5948.1000210

Copyright: (c) 2015 Paudel YP, et al. This is an open-access article distributed under the terms of the Creative Commons Attribution License, which permits unrestricted use, distribution, and reproduction in any medium, provided the original author and source are credited. 
Citation: Paudel YP, Qin W (2015) Two Bacillus Species Isolated from Rotting Wood Samples are Good Candidates for the Production of Bioethanol using Agave Biomass. J Microb Biochem Technol 7:4 218-225. doi:10.4172/1948-5948.1000210

abilities of Bacillus sp. K1 (NCBI Accession no. KP987117) and Bacillus sp. A0 (NCBI Accession no. KP974676); which we previously isolated from rotting wood samples were tested. Cellulomonas xylanilytica and Escherichia coli BL21 were used as positive and negative controls respectively [4].

\section{Screening of cellulase activity}

For the screening of cellulase producing activity of bacterial strains, each strain was grown with positive and negative controls in $5 \mathrm{ml} \mathrm{LB}$ broth at $30^{\circ} \mathrm{C}$ at $200 \mathrm{rpm}$ separately. Five microliters of each sample was inoculated on agar plates which contain $5.0 \mathrm{~g} / \mathrm{L}$ agave, $1.0 \mathrm{~g} / \mathrm{L} \mathrm{NaNO}_{3}$, $1.0 \mathrm{~g} / \mathrm{L} \mathrm{K}_{2} \mathrm{HPO}_{4}, 1.0 \mathrm{~g} / \mathrm{L} \mathrm{KCl}, 0.5 \mathrm{~g} / \mathrm{L} \mathrm{MgSO}_{4}, 0.5 \mathrm{~g} / \mathrm{L}$ yeast extract, 1.0 $\mathrm{g} / \mathrm{L}$ glucose, $15.0 \mathrm{~g} / \mathrm{L}$ agar. After incubating all the plates for $48 \mathrm{~h}$ at $30^{\circ} \mathrm{C}$, the plates were checked with Gram's iodine solution [9]. The diameter of halo region (D) and bacterial colony (d) were measured to show the hydrolysis ability which can be expressed as $(D / d)^{2}$.

\section{Determination of reducing sugar and cellulase activity}

For the determination of reducing sugar from the Agave biomass degradation, the bacterial strains were grown overnight in LB broth medium. Then $200 \mu \mathrm{l}$ of the overnight LB grown bacteria were transferred to $50 \mathrm{ml}$ minimal salt medium containing $0.1 \mathrm{~g} / \mathrm{L} \mathrm{NaNO}_{3}$, $\mathrm{K}_{2} \mathrm{HPO}_{4}, 0.1 \mathrm{~g} / \mathrm{L}, \mathrm{KCl} 0.1 \mathrm{~g} / \mathrm{L}$ and $\mathrm{MgSO}_{4}, 0.05 \mathrm{~g} / \mathrm{L}$ and $5 \%$ Agave biomass. The bacterial strains were incubated at $30^{\circ} \mathrm{C}$, shaking $200 \mathrm{rpm}$ for seven days. The reducing sugars and cellulase activity were detected by using 3,5-dinitrosalicylic acid (DNS) method [10]. For this, $1 \mathrm{ml}$ of bacterial culture was harvested from each sample. It was centrifuged for $2 \mathrm{~min}$ at $15000 \mathrm{~g}$ carboxymethyl cellulose (CMC) was used as substrate for cellulase activity. Briefly, $20 \mu \mathrm{l}$ of enzyme supernatant was added to $80 \mu$ of substrate buffer $(0.5 \%$ CMC in $0.05 \mathrm{M}$ potassium phosphate buffer, $\mathrm{pH}$ 6.0) and incubated at $50^{\circ} \mathrm{C}$ for $30 \mathrm{~min}$. The reducing sugar released as glucose was determined. Microtitre plate was used for recording the absorbance at $540 \mathrm{~nm}$ using Epoch microplate spectrophotometer (BioTek). The reducing sugar was measured up to seven days of incubation. After seven days, the bacterial strain's survival was confirmed by the drop plate method.

\section{SDS-Polyacrylamide gel electrophoresis (PAGE)}

The cellulase was confirmed by using SDS-PAGE according to the method of Laemmli [11] using Bio-Rad electrophoresis apparatus. The protein marker and enzyme were allowed to run simultaneously to determine the molecular weight of the enzyme. After completion of the electrophoresis, coomassie brilliant blue R-250 was use to stain the gel. The gel containing $0.25 \% \mathrm{CMC}$ was used for detection of cellulase activity. The gel was then washed with $2 \%$ Triton X-100 for $30 \mathrm{~min}$. Then, it was transferred in $\mathrm{pH} 7$ and incubated at $50^{\circ} \mathrm{C}$ for $30 \mathrm{~min}$. After that the gel was stained with $0.1 \%$ Congo red solution and the over staining was removed with $1 \mathrm{M} \mathrm{NaCl}$ to visualize the clear bands of cellulase activity.

\section{Ethanol determination}

The bacterial strains were grown for 7 days in $50 \mathrm{ml}$ minimal salt medium containing $0.1 \mathrm{~g} / \mathrm{L} \mathrm{NaNO}_{3}, \mathrm{~K}_{2} \mathrm{HPO}_{4} 0.1 \mathrm{~g} / \mathrm{L}, \mathrm{KCl} 0.1 \mathrm{~g} / \mathrm{L}$ and $\mathrm{MgSO}_{4} 0.05 \mathrm{~g} / \mathrm{L}$ and $5 \%$ Agave biomass at $30^{\circ} \mathrm{C}$, shaking at $200 \mathrm{rpm} .1$ $\mathrm{ml}$ aliquot of the cultured bacteria was centrifuged for $1 \mathrm{~min}$ at 17000 g. The supernatant was used for bioethanol analysis. The samples were then analysed by using micro-dichromate method [12]. In this method, there is complete oxidation of ethanol by dichromate in the presence of sulphuric acid with the formation of acetic acid. Dichromate $\mathrm{Cr}_{2} \mathrm{O}_{7}$ is yellowish in color and the reduced chromic product $\left(\mathrm{Cr}^{3+}\right)$ is intensely green. A standard curve of ethanol with was made with different concentrations of ethanol the absorbance of the samples was read at $584 \mathrm{~nm}$.

\section{Morphology of Agave fibre}

Scanning Electron Microscope (SEM) was used to observe the morphological changes of Agave fiber. The samples treated with bacterial strains up to 7 days were collected along with the control (samples without bacterial treatment). Each sample was washed with $0.1 \mathrm{M}$ phosphate buffer and dehydrated with ethanol. After this, the samples were dried at room temperature and coated with gold in in
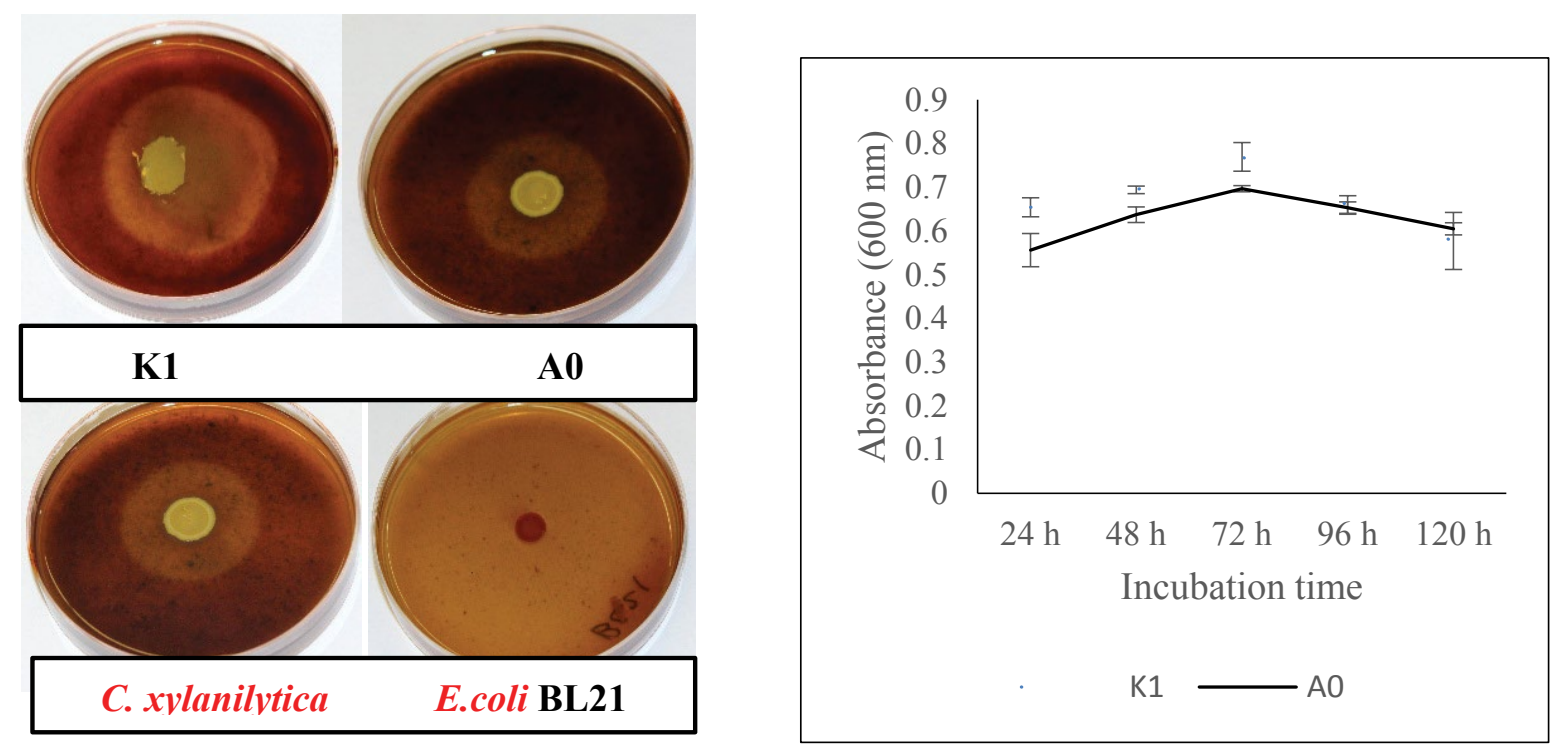

Figure 1: (A) Agave plate assay and (B) bacterial growth in $C M C$ minimal salt liquid medium 
a Denton-DeskII sputter coater (Denton Vacuum USA, Moorestown, NJ). The samples were observed on SEM (Hitachi SU-70, Japan).

\section{Statistical analysis}

All the experiments were performed in triplicates and the results are expressed in terms of mean \pm SD (standard deviation). The statistical analysis of data was performed by one way ANOVA followed by Tukey's HSD test $(p<0.05)$ using SPSS system.

\section{Results and Discussion}

\section{Cellulase screening using Agave as the source of carbon}

In this research, both the bacterial strains showed the area of depolymerisation which proved their ability for hydrolysis of Agave biomass (Figure 1A). The negative control did not have any cellulase activity so there was no halo region. The production of halo region is due to the depolymerisation of the cellulose by cellulase. As shown in Table 1 , the hydrolysis ability of strain $\mathrm{K} 1$ is and $\mathrm{A} 0$ is more than the positive control after $48 \mathrm{~h}$ of incubation. The hydrolysis ability values for strains K1 and A0 are 19.04 and 14.27. This showed that both the bacteria have better ability than C. xylanilytica for hydrolysis of Agave biomass. As reported by other researchers, Bacillus strains have potentiality for the degradation of lignocellulose [13].

\section{Cellulase activity and reducing sugar production}

Since, these bacterial isolates showed maximum growth after three days of incubation (Figure 1B); the cellulase activity was assessed at 72 $\mathrm{h}$ of incubation by growing the bacteria in minimal salt medium with CMC and with Agave biomass respectively. The CMCase activity of strains was compared with positive control C. xylanilytica and negative control E. coli BL21 (Figure 2A). While using CMC as a source of carbon during enzyme production, the CMCase activity of strain $\mathrm{K} 1$ was $5.21 \pm 0.21 \mathrm{U} / \mathrm{ml}$ and A0 produced $4.3 \pm 0.25 \mathrm{U} / \mathrm{ml}$ CMCase. Both the strains produced higher CMCase than the positive control and the negative control did not show any CMCase activity. Similarly, while using the Agave biomass as a source of carbon during fermentation the CMCases activities of $\mathrm{K} 1$ and $\mathrm{A} 0$ were $3.82 \pm 0.24 \mathrm{U} / \mathrm{ml}$ and $3.5 \pm 0.12$ $\mathrm{U} / \mathrm{ml}$, respectively (Figure $2 \mathrm{~B}$ ). The enzyme activity of these isolates was found higher than those of the most widely studied bacteria and fungi, which have received wide attention for commercial production of cellulase [14].

The production of reducing sugar was maximum on the third day of incubation and then it was decreased considerably (Table 2). The Bacillus spp. K1 and A0 produced $0.729 \pm 0.027$ and $0.696 \pm 0.016 \mathrm{~g}$ reducing sugars respectively by the degradation of per gram of Agave fibers. The reduction in the reducing sugar production after $72 \mathrm{~h}$ might be due to the fact that the production of bioethanol requires consumption and conversion of sugars during the bacterial growths. The production of reducing sugar might have been decreased with the increase in incubation period which could be due to the consumption and conversion to other chemicals by the bacterial strains. Further, the consumption of reducing sugars by bacteria prevented the inhibition effect of these sugars on enzymatic hydrolysis and ultimately endproduct production, producing ethanol. Also, after seven days of incubation, the survival rate of the both the strains were $100 \%$.

\section{SDS-Polyacrylamide gel electrophoresis (PAGE) and} zymogram analysis

The molecular weight of the crude cellulases produced by K1 and

\begin{tabular}{|c|c|c|c|c|}
\hline Bacterial isolates & Halo diameter $\mathbf{( d , ~ c m ) ~}$ & Colony diameter (d, cm) & Hydrolysis ability (D/d) & Species \\
\hline K1 & 4.8 & 1.1 & 19.04 \\
\hline A0 & 3.4 & 0.9 & 14.27 \\
\hline +ve control & 3.3 & 0.9 & 13.44 \\
\hline -ve control & - & 0.7 & Bacillus sp. K1 & C. xylanilytica \\
\hline
\end{tabular}

Table 1: Hydrolysis ability of the bacterial isolates with positive (+ve) and negative (-ve) controls.
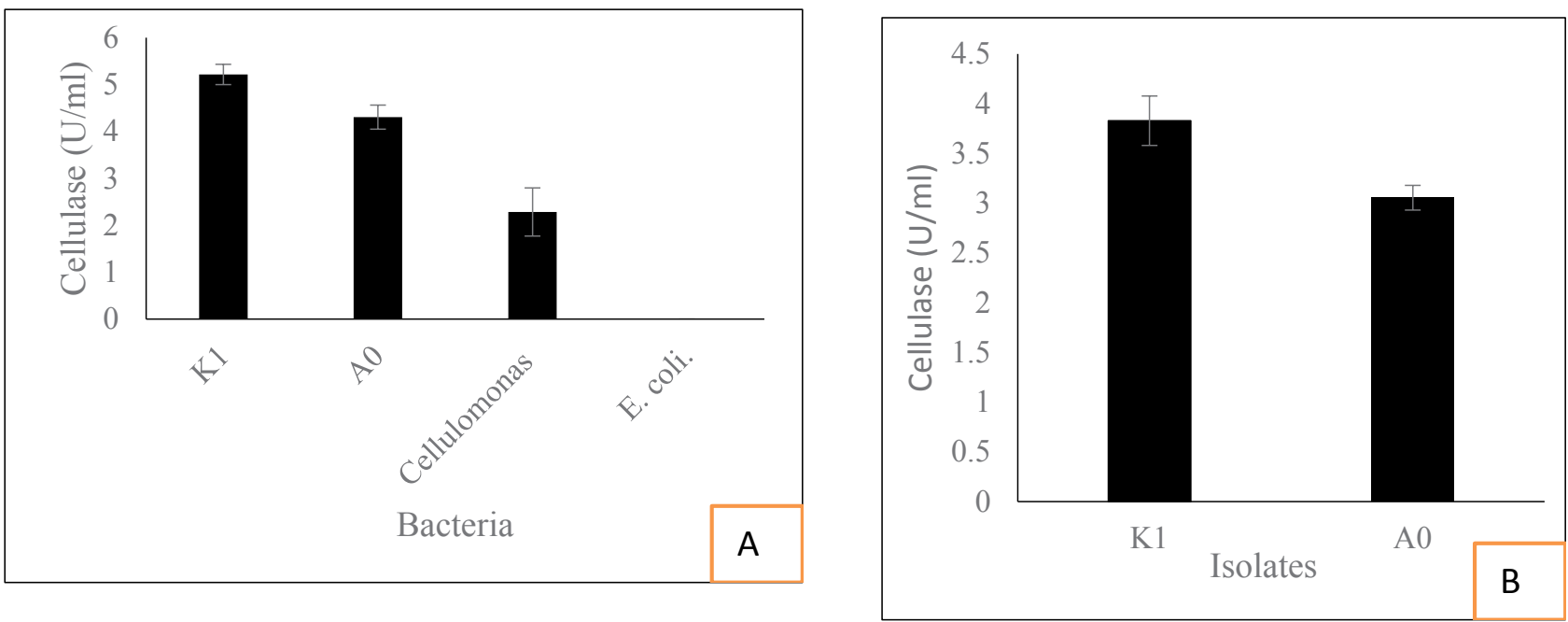

Figure 2: Cellulase activity using (A) $C M C$ and $(B)$ Agave biomass. 
A0 were estimated $\sim 36 \mathrm{kDa} \sim 40 \mathrm{kDa}$ respectively (Figure 3). Many researchers reported that the molecular weight of cellulases produced by Bacillus species ranges from $37-43 \mathrm{kDa}$ [15-18]. However, other reports show the molecular weight of cellulases by other species of Bacillus to be $53-78 \mathrm{kDa}[19-21]$.

\section{Production of ethanol by degradation of Agave biomass}

The microorganisms require nutrients for energy generation and enzymes production. The source of lignocellulosic biomass functions as the main source of carbon. The production of ethanol is influenced by different factors such as carbon source, nitrogen source, culture conditions, etc. [22]. The results showed that both the strains produced ethanol efficiently. The maximum bioethanol was produced by strain $\mathrm{K} 10.435 \mathrm{~g} / \mathrm{g}$ of Agave biomass and the strain A0 produced $0.397 \mathrm{~g} / \mathrm{g}$ ethanol at the $4^{\text {th }}$ day of incubation which was significantly different to its production on the other days by both the strains. The ethanol yield was decreased significantly after 4 days of incubation by both the bacterial isolates (Figure 4). It might be due to the toxic effect of ethanol to the bacteria or that they are metabolizing it to another product. Further, these Bacillus strains had ability for simultaneous saccharification and fermentation and were able to convert the reducing sugar to ethanol from the first day of incubation to day seven without pre-treatment of Agave biomass. The enzymatic hydrolysis is helpful to give better ethanol yields than thermal acid hydrolysis after fermentation [23]. During enzymatic hydrolysis, if the biomass is pretreated, the production of ethanol is always higher. Also, the hydrolysis ability and ethanol tolerance of microbial strains is different.

The development of low cost and high efficiency substrates like Agave in industrial scale is very important. However, the conversion of Agave lignocellulosic biomass to bioethanol and other value added products is limited by several factors such as the complexity in pre-

\begin{tabular}{|c|c|c|}
\hline Incubation time (days) & $\mathbf{Y}_{\text {g/g Reducing sugar }}$ (A0) & Y \\
\hline 1 & $0.414 \pm 0.017$ & $0.470 \pm 0.027$ \\
\hline 2 & $0.561 \pm 0.014$ & $0.590 \pm 0.015$ \\
\hline 3 & $0.696 \pm 0.016$ & $0.729 \pm 0.027$ \\
\hline 4 & $0.490 \pm 0.032$ & $0.545 \pm 0.012$ \\
\hline 5 & $0.371 \pm 0.027$ & $0.415 \pm 0.026$ \\
\hline 7 & $0.283 \pm 0.020$ & $0.312 \pm 0.022$ \\
\hline
\end{tabular}

$\mathrm{Y}_{\mathrm{g} / \mathrm{g} \text { Reducing sugar }}=$ Reducing sugars $(\mathrm{g} / \mathrm{L}) / 50 \mathrm{~g}$ agave fiber per liter

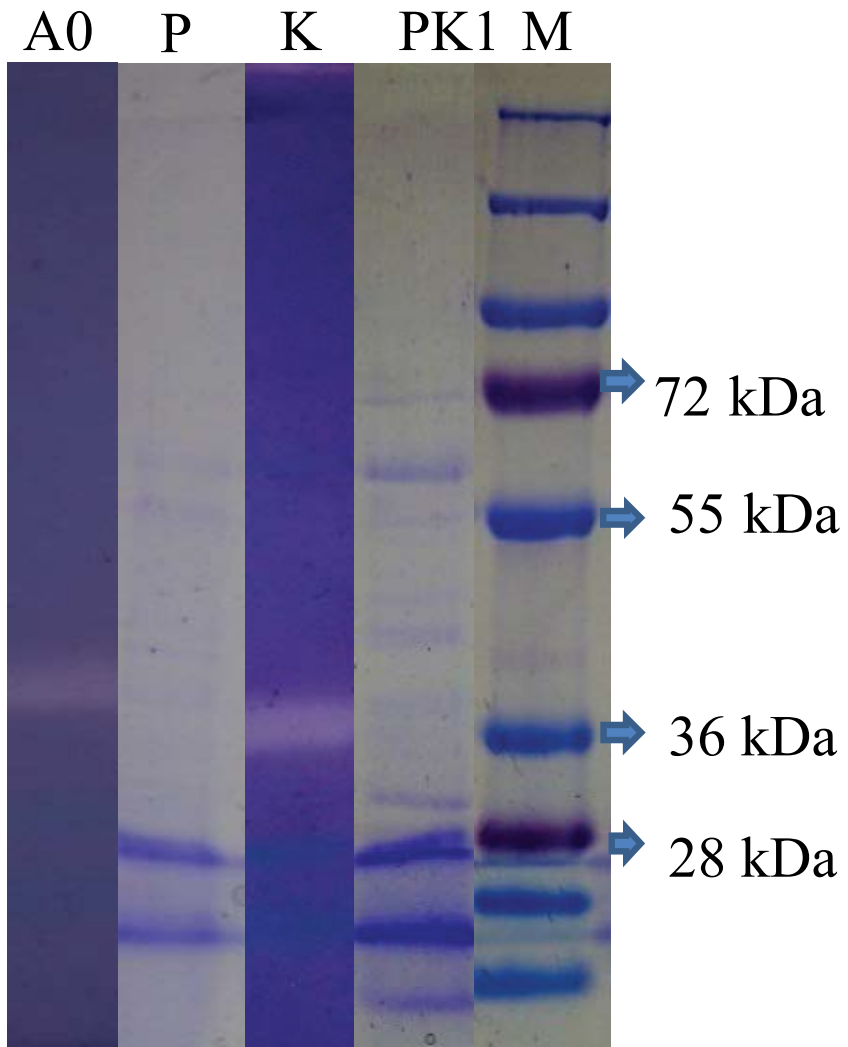

Figure 3: SDS-PAGE and zymogram of crude cellulase enzyme. (M-Marker, PK1-Protein in supernatant and K1-cellulase by strain K1, PA0-Protein in supernatant and A0 cellulase by strain A0. Based on the gel, the molecular wt. of the enzyme was estimated about $\sim 36 \mathrm{kDa}$ for $\mathrm{K} 1$ and $\sim 40 \mathrm{kDa}$ for $\mathrm{A} 0$ ). 
Citation: Paudel YP, Qin W (2015) Two Bacillus Species Isolated from Rotting Wood Samples are Good Candidates for the Production of Bioethanol using Agave Biomass. J Microb Biochem Technol 7:4 218-225. doi:10.4172/1948-5948.1000210

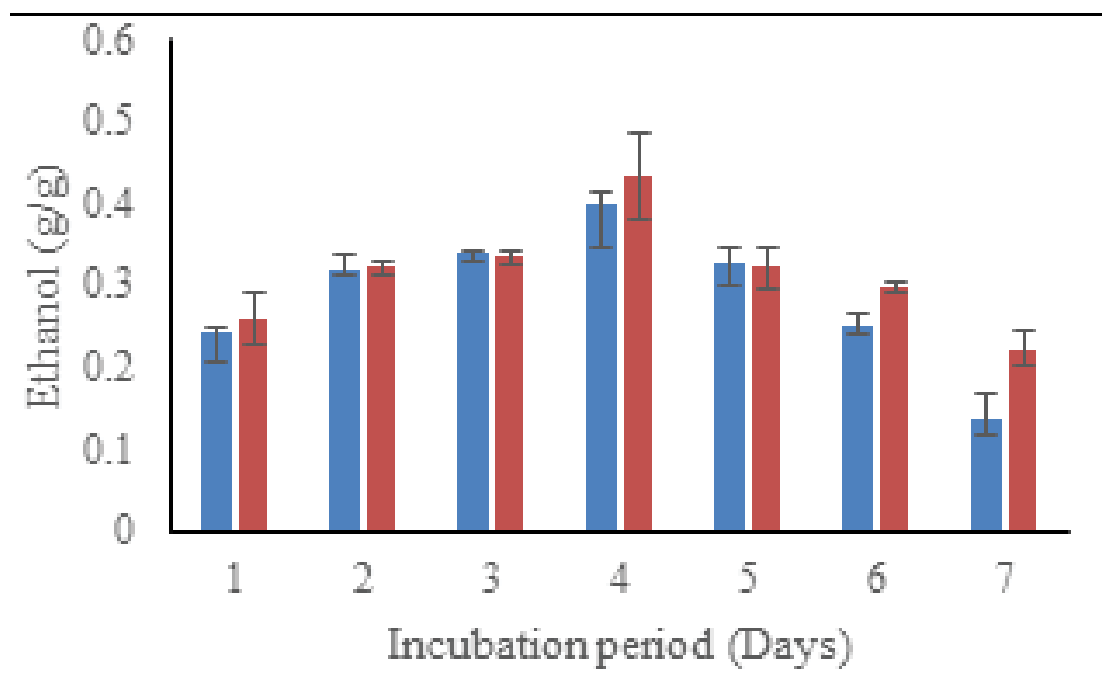

$\mathrm{A} 0 \mathrm{~K} 1$

Figure 4: Ethanol yield from degradation of Agave biomass expressed in Ethanol $(\mathrm{g} / \mathrm{L}) /(50 \mathrm{~g}$ Agave fiber per liter.
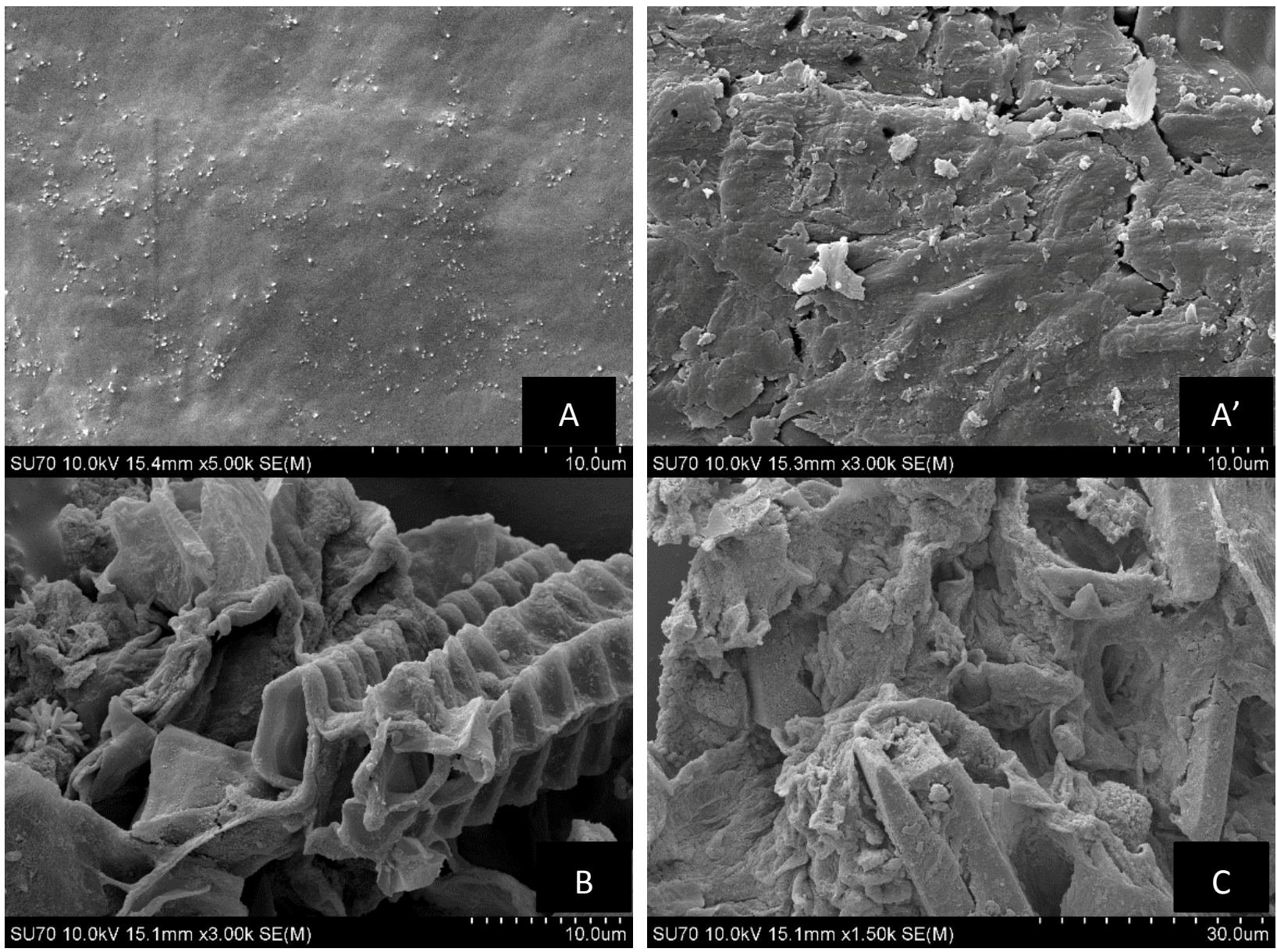

Figure 5: Scanning electron microscopy (SEM) images of Agave fibers. (A and $A^{\prime}$ ) Untreated agave leaf structure (control) during an incubation period of 7 days. (B and C) Bacillus sp. K1 and Bacillus sp. A0 treated agave leaf structures after 7 days of incubation. 
treatment, low conversion efficiency from pentose to ethanol, and high production cost of the enzyme. In this research both of the cellulase producing Bacillus strains could degrade the untreated Agave biomass and produced ethanol. The use of untreated biomass could eliminate the pre-treatment step. Ultimately, it lowers the production cost of ethanol by combining the hydrolysis and fermentation steps together. Similar reports of ethanol production by Bacillus strains from Agave biomass have been found by other researchers [4]. Other microorganisms such as yeasts could also produce ethanol from Agave biomass fermentation [24-26].

There has been a considerable interest in the production of ethanol using biomass fermentation on a large scale. There is a focus towards high yield of ethanol with the use of lignocellulosic biomass with the high productivity to reduce the cost of production. During the hydrolysis process of biomass using enzymes like cellulase, purified enzymes with optimized conditions give better result for degrading cellulose and hemicellulose of the biomass [27]. However, one of the major problems with the production of bioethanol from lignocellulosic biomass is the high production cost of the cellulolytic enzymes because most of the commercially available cellulytic enzymes are not efficient for simultaneous saccharification and fermentation process. The cellulolytic microorganisms possessing hydrolytic and fermentative abilities are more efficient for the bioethanol production from lignocellulosic biomass [28]. In this research the two Bacillus strains could produce cellulase efficiently by using Agave biomass and helped in the hydrolysis and fermentation of this lignocellulosic biomass to produce ethanol.

\section{Morphology observation of Agave fiber}

The control (untreated) Agave leaf surface was smooth after 7 days of incubation which indicates no degradation of the fibers (Figures $5 \mathrm{~A}$ and $\left.5 \mathrm{~A}^{\prime}\right)$. The bacteria treated images show the broken cell wall with rough surface. After the bacterial treatment, the fiber surface was broken forming a large number of crevasses (Figures $5 B$ and $5 \mathrm{C}$ ). The degraded cell wall allows more cell wall degrading enzymes. Initially, the fine fibers are interwoven into a complex structure. The damage of cytoderm of the fiber helps to depolymerisation of cellulose and hemicellulose of Agave. Both of the Bacillus strains were able to damage the cytoderm of Agave fiber which helped to increase the cellulose and hemicellulose depolymerisation. This finding was similar with the findings of other researchers who reported that Bacillus species have ability to degrade the cellulose, hemicellulose and lignin $[29,30]$.

\section{Conclusion}

In this research, the two Bacillus species isolated from rotting wood samples were assayed for cellulase activity. Both of the strains exhibited the higher cellulase activity than many other bacterial and fungal species. While using Agave biomass as a source of carbon, the CMCase activity of $\mathrm{K} 1$ was $3.82 \pm 0.24 \mathrm{U} / \mathrm{ml}$ and $\mathrm{A} 0$ showed this activity as $3.5 \pm$ $0.12 \mathrm{U} / \mathrm{ml}$. Based on SDS-PAGE analysis, the molecular weights of the cellulases produced by $\mathrm{K} 1$ and $\mathrm{A} 0$ were found $\sim 36 \mathrm{kDa}$ and $\sim 40 \mathrm{kDa}$, respectively. By using untreated Agave biomass, the maximum ethanol production was $0.435 \mathrm{~g} / \mathrm{g}$ Agave biomass by strain K1. Similarly, isolate A0 produced $0.397 \mathrm{~g} / \mathrm{g}$ ethanol on the $4^{\text {th }}$ day of incubation. Both of these strains are of particular interest for producing maximum cellulase using lignocellulosic biomass which might be valuable for biorefining industries for the production of bioethanol. Also, the Agave biomass was found as a good source of lignocellulose without pre-treatment.
Further research is required for improving the ethanol yield by using different fermentation conditions and for detecting the other important chemicals produced during the fermentation of Agave biomass.

\section{References}

1. Smith AM (2008) Prospects for increasing starch and sucrose yields for bioethanol production. Plant J 54: 546-558.

2. Pimentel D (2010) Biofuels, Solar and Wind as Renewable Energy Systems: Benefits and Risks. Springer

3. Yan X, Tan DK, Inderwildi OR, Smith JAC, King DA (2011) Life cycle energy and greenhouse gas analysis for agave-derived bioethanol. Energy Environ Sci 4: 3110-3121.

4. Xiong L, Maki M, Guo Z, Mao C, Qin W (2014) Agave Biomass is Excellent for Production of Bioethanol and Xylitol Using Bacillus Strain $65 S 3$ and Pseudomonas Strain CDS3. J Biobased Mater Bio 8: 422-428.

5. Mylsamy K, Rajendran I (2010) Investigation on physio-chemical and mechanical properties of raw and alkali-treated Agave americana fiber. J Reinf Plast Comp 29: 2925-2935.

6. Mani S, Tabil LG, Opoku A (2002) Ethanol from agricultural crop residuesAn overview. The Society for engineering in Agriculture, food and biological systems Paper No: MBSK 02-217.

7. Sun $Y$, Cheng J (2002) Hydrolysis of lignocellulosic materials for ethanol production: A review. Bioresour Technol 83: 1-11.

8. Pandey S, Singh S, Yadav AN, Nain L, Saxena AK (2013) Phylogenetic diversity and characterization of novel and efficient cellulase producing bacterial isolates from various extreme environments. Biosci Biotechnol Biochem 77: 1474-1480.

9. Kasana RC, Salwan R, Dhar H, Dutt S, Gulati A (2008) A rapid and easy method for the detection of microbial cellulases on agar plates using gram's iodine. Curr Microbiol 57: 503-507.

10. Miller GL (1959) Use of DNS reagent for the measurement of reducing sugar Anal Chem 31: 426-428.

11. Laemmli UK (1970) Cleavage of structural proteins during the assembly of the head of bacteriophage T4. Nature 227: 680-685

12. Caputi A, Ueda M, Brown T (1968) Spectrophotometric determination of ethanol in wine. Am J Enol Vitic 19: 160-165

13. Howard RL, Abotsi E, Van Rensburg EJ, Howard S (2004) Lignocellulose biotechnology: Issues of bioconversion and enzyme production. Afr J Biotechnol 2: 602-619.

14. Kang SW, Park YS, Lee JS, Hong SI, Kim SW (2004) Production of cellulase and hemicellulases by Aspergillus niger KK2 from lignocellulosic biomass. Bioresour Technol 91: 153-156.

15. Bischoff KM, Rooney AP, Li XL, Liu S, Hughes SR (2006) Purification and characterization of a family 5 endoglucanase from a moderately thermophilic strain of Bacillus licheniformis. Biotechnol Lett 28: 1761-1765

16. Hakamada Y, Endo K, Takizawa S, Kobayashi T, Shirai T, et al. (2002) Enzymatic properties, crystallization, and deduced amino acid sequence of an alkaline endoglucanase from Bacillus circulans. Biochim Biophys Acta 1570: 174-180.

17. Mawadza C, Hatti-Kaul R, Zvauya R, Mattiasson B (2000) Purification and characterization of cellulases produced by two Bacillus strains. J Biotechnol 83: 177-187.

18. Ozaki K, Ito S (1991) Purification and properties of an acid endo-,4-betaglucanase from Bacillus sp. KSM-330. J Gen Microbiol 137: 41-48.

19. Li YH, Ding M, Wang J, Xu GJ, Zhao F (2006) A novel thermoacidophilic endoglucanase, Ba-EGA, from a new cellulose-degrading bacterium, Bacillus sp.AC-1. Appl Microbiol Biotechnol 70: 430-436.

20. Christakopoulos P, Hatzinikolaou DG, Fountoukidis G, Kekos D, Claeyssens $M$, et al. (1999) Purification and mode of action of an alkali-resistant endo4-beta-glucanase from Bacillus pumilus. Arch Biochem Biophys 364: 61-66.

21. Okoshi H, Ozaki K, Shikata S, Oshino K, Kawai S, et al. (1990) Purification and characterization of multiple carboxymethyl cellulases from Bacillus sp. KSM522. Agr Biol Chem 54: 83-89. 
Citation: Paudel YP, Qin W (2015) Two Bacillus Species Isolated from Rotting Wood Samples are Good Candidates for the Production of Bioethanol using Agave Biomass. J Microb Biochem Technol 7:4 218-225. doi:10.4172/1948-5948.1000210

22. Tsigie YA, Wu CH, Huynh LH, Ismadji S, Ju YH (2013) Bioethanol production from Yarrowia lipolytica Po1g biomass. Bioresour Technol 145: 210-216.

23. Villegas-Silva PA, Toledano-Thompson T, Canto-Canché BB, LarquéSaavedra A, Barahona-Pérez LF1 (2014) Hydrolysis of Agave fourcroydes Lemaire (henequen) leaf juice and fermentation with Kluyveromyces marxianus for ethanol production. BMC Biotechnol 14: 14

24. Cáceres-Farfán $M$, Lappe $P$, Larqué-Saavedra $A$, Magdub-Méndez $A$, Barahona-Pérez L (2008) Ethanol production from henequen (Agave fourcroydes Lem.) juice and molasses by a mixture of two yeasts. Bioresour Technol 99: 9036-9039.

25. López-Alvarez A, Díaz-Pérez AL, Sosa-Aguirre C, Macías-Rodríguez L, Campos-García J (2012) Ethanol yield and volatile compound content in fermentation of agave must by Kluyveromyces marxianus UMPe-1 comparing with Saccharomyces cerevisiae baker's yeast used in tequila production. J Biosci Bioeng 113: 614-618.

26. Murugan CS, Rajendran S (2013) Bioethanol Production from Agave Leaves
Using Saccharomyces cerevisiae (MTCC 173) and Zymomonas mobilis (MTCC 2427). Intl J Microbiol Res. 4: 23-26.

27. Prasad MP, Sethi R, Tamilarasan M, Subha KS (2009) Production of bioethanol using various agricultural raw materials by two step enzymatic process. J Adv Biotechnol 9: 41-43.

28. Limayem A, Ricke SC (2012) Lignocellulosic biomass for bioethanol production: Current perspectives, potential issues and future prospects. Prog Energy Combust Sci 38: 449-467.

29. Maki ML, Idrees A, Leung KT, Qin W (2012) Newly isolated and characterized bacteria with great application potential for decomposition of lignocellulosic biomass. J Mol Microbiol Biotechnol 22: 156-166.

30. Wongwilaiwalin S, Rattanachomsri U, Laothanachareon T, Eurwilaichitr L, Igarashi $Y$, et al. (2010) Analysis of a thermophilic lignocellulose degrading microbial consortium and multi-species lignocellulolytic enzyme system. Enzyme Microb Technol 47: 283-290. 